\title{
Two Acylated Isoscutellarein Glucosides with Anti-Inflammatory and Antioxidant Activities Isolated from Endemic Stachys Subnuda Montbret \& Aucher ex Benth
}

\author{
Ali Sen, ${ }^{1, \star}$ Fatih Goger, ${ }^{2}$ Ahmet Dogan ${ }^{3}$ and Leyla Bitis ${ }^{1}$ \\ ${ }^{1}$ Department of Pharmacognosy, Faculty of Pharmacy, Marmara University, Istanbul, Turkey, \\ ${ }^{2}$ Department of Pharmacognosy, Faculty of Pharmacy, Anadolu University, Eskisehir, Turkey \\ ${ }^{3}$ Department of Pharmaceutical Botany, Faculty of Pharmacy, Marmara University, Istanbul, Turkey \\ *Corresponding author: E-mail: ali.sen@marmara.edu.tr; alisenfb@hotmail.com \\ Phone: +90 53593878 94; Fax: +90 216345 29 52; e-mail
}

Received: 12-27-2018

\begin{abstract}
In this study, we report anti-inflammatory and antioxidant activities of two acylated isoscutellarein glucosides isolated from ethyl acetate extract of Stachys subnuda aerial part. 4'-O-methylisoscutellarein-7-O-2"'-O-(6"')-O-acetyl- $\beta$-D-allopyranosyl)- $\beta$-D-glucopyranoside (SS1) and isoscutellarein-7-O-2"-O-(6"'-O-acetyl- $\beta$-D-allopyranosyl)- $\beta$-D-glucopyranoside (SS2) were isolated as major compounds from ethyl acetate extract (SSEA). Also, 2 hydroxycinnamic acid derivatives, and 5 isoscutellarein glucoside derivatives in the SSEA were identified using LC-MS/MS. SS1 with IC $\mathrm{I}_{50}$ values of 2.35 and $1.98 \mu \mathrm{g} / \mathrm{mL}$ and SS2 with $\mathrm{IC}_{50}$ values 13.94 and $12.76 \mu \mathrm{g} / \mathrm{mL}$ showed fairly strong antioxidant activity against DPPH (1,1-diphenyl-2-picrylhydrazyl) and ABTS (2,2'-azino-bis-3-ethylbenzthiazoline-6-sulphonic acid) radicals, respectively. SS1 and SS2 inhibited 5-lipoxygenase (5-LOX) activity with $\mathrm{IC}_{50}$ values of 47.23 and $41.60 \mu \mathrm{g} / \mathrm{mL}$, respectively. The results demonstrated that SS1 and SS2 have significant anti-inflammatory and antioxidant potential. Acylated flavonoid glycosides have been first reported for Stachys subnuda. Also, the activities of SS1 and SS2 have been investigated for the first time in this study.
\end{abstract}

Keywords: Stachys subnuda; acylated flavonoids; anti-inflammatory activity; antioxidant activity; LC-MS/MS

\section{Introduction}

The Stachys genus is one of the largest species of the Lamiaceae family and is represented by about 300 species worldwide. ${ }^{1}$ Also, Turkey is one of the richest countries in terms of variety of Stachys species and this genus is represented by 91 species with an endemism rate of $48 \%$. Stachys species known as "Deli sage" or "Mountain tea" in Anatolia are used in the skin diseases, ulcers, cancer, respiratory diseases and kidney diseases by the people because of their antibacterial, anti-inflammatory, antipyretic, antioxidant and cytotoxic effects. ${ }^{2}$ In many countries, especially in the Mediterranean regions, Stachys species are consumed as herbal tea (Mountain Tea), food and herbal remedies. ${ }^{3}$

There is only one report on the chemical composition and biological activity of the essential oil of Stachys subnuda in the literature. ${ }^{4}$ However, no study on isolation of flavonoids from this species and their biological activities have yet been reported. In the studies on other Stachys species, it has revealed that secondary metabolites are generally iridoids, flavone glycosides, diterpenes and essential oils. $^{2,5-7}$ Also, it has been reported that various extracts of Stachys species have antioxidant, anti-proliferative, anti-inflammatory, antiulcer, antinociceptive, antimicrobial activities. ${ }^{8-10}$ There is no scientific information on chemical composition of Stachys subnuda ethyl acetate extract and anti-inflammatory and antioxidant activities of its active major compounds. Therefore, the aim of this study was to test anti-inflammatory and antioxidant activities of major compounds isolated from ethyl acetate extract of aerial parts of endemic Stachys subnuda Montbret \& Aucher Ex Benth. 


\section{Experimental}

\section{1. Plant Material}

Aerial parts of plant were collected in the flowering period from the Tunceli province of Turkey in 2015 and identified by Dr. Ahmet Dogan, a botanist of the Faculty of Pharmacy, University of Marmara. Voucher specimens were deposited in the Herbarium of the Faculty of Pharmacy, Marmara University (MARE No: 17720).

\section{2. Extraction}

Dried and ground aerial parts of Stachys subnuda (10 g) for activities were extracted with $\mathrm{CH}_{3} \mathrm{OH}(3 \times 100 \mathrm{~mL})$, using an ultrasonic bath. After filtration and evaporation, the residue (SSM) was dissolved in $50 \mathrm{~mL} 50 \%$ aqueous methanol, and subjected to solvent-solvent partition between $\mathrm{n}$-hexane $(3 \times 50 \mathrm{~mL})$, chloroform $(3 \times 50 \mathrm{~mL})$ and ethyl acetate $(3 \times 50 \mathrm{~mL})$. The $\mathrm{n}$-hexane, chloroform, ethyl acetate and aqueous methanol extracts were coded as SSH, SSC, SSEA and SSAM, respectively. Also, about $140 \mathrm{~g}$ of the plant was weighed for isolation and similar extraction procedures described above were carried out. All extracts were stored under refrigeration for further analysis.

\section{3. In vitro Anti-Inflammatory Activity}

The anti-inflammatory activity was evaluated according to the method described by Phosrithong et al. ${ }^{11}$ An aliquot of $500 \mu \mathrm{L}$ at different concentrations of isolated compounds was added to $250 \mu \mathrm{L}$ of $0.1 \mathrm{M}$ borate buffer $\mathrm{pH} 9.0$, followed by addition of $250 \mu \mathrm{L}$ of type $\mathrm{V}$ soybean lipoxygenase solution in buffer $(20.000 \mathrm{U} / \mathrm{mL})$. After the mixture was incubated at $25^{\circ} \mathrm{C}$ for $5 \mathrm{~min}, 1000 \mu \mathrm{L}$ of $0.6 \mathrm{mM}$ linoleic acid solution was added, mixed well and the change in absorbance at $234 \mathrm{~nm}$ was recorded for $6 \mathrm{~min}$. Indomethacin was used as a reference standard. The percent inhibition was calculated from the following equation:

$$
\% \text { inhibition }=\left[\left(\mathrm{A}_{\text {control }}-\mathrm{A}_{\text {sample }}\right) / \mathrm{Ac}_{\text {ontrol }}\right] \times 100
$$

A dose-response curve was plotted to determine the $\mathrm{IC}_{50}$ values. $\mathrm{IC}_{50}$ is defined as the concentration sufficient to obtain $50 \%$ of a maximum anti-inflammatory activity. All tests and analyses were performed in triplicates.

\section{4. DPPH Radical Scavenging Activity}

Free radical scavenging capacity of isolated compounds and extracts were evaluated according to the previously reported procedure using the stable DPPH. ${ }^{12}$ Briefly, $10 \mu \mathrm{L}$ of sample in DMSO at different concentrations $(125-0.24 \mu \mathrm{g} / \mathrm{mL})$ were added to $190 \mu \mathrm{L}$ methanol solution of DPPH $(0.1 \mathrm{mM})$ in a well of 96 -well plate. The mixture was shaken vigorously and allowed to stand in the dark at room temperature for $30 \mathrm{~min}$. Absorbance read- ings were taken at $517 \mathrm{~nm}$. The percent radical scavenging activity of extracts and standard against DPPH were calculated according to the following:

$$
\begin{aligned}
& \text { DPPH radical-scavenging activity }(\%)= \\
& \quad=\left[\left(\mathrm{A}_{0}-\mathrm{A}_{1}\right) / \mathrm{A}_{0}\right] \times 100
\end{aligned}
$$

where $A_{0}$ is the absorbance of the control (containing all reagents except the test extracts or compounds), and $A_{1}$ is the absorbance of the extracts/standard. Extracts or compounds concentration providing $50 \%$ inhibition $\left(\mathrm{IC}_{50}\right)$ was calculated from the graph plotting inhibition percentage against extracts concentration. Tests were carried out in triplicate. BHA, Ascorbic acid and Trolox were used as positive control.

\section{5. ABTS Radical-Scavenging Activity}

Free radical scavenging capacity of isolated compounds and extracts was evaluated according to the previously reported procedure. ${ }^{12}$ ABTS radical cations were

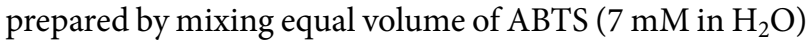
and potassium persulfate $\left(4,9 \mathrm{mM}\right.$ in $\left.\mathrm{H}_{2} \mathrm{O}\right)$, allowing them to react for $12-16 \mathrm{~h}$ at room temperature in the dark. Then, ABTS radical solution was diluted with $96 \%$ ethanol to an absorbance of about 0.7 at $734 \mathrm{~nm} .10 \mu \mathrm{L}$ of sample in DMSO at different concentrations $(125-0.24 \mu \mathrm{g} / \mathrm{mL})$ were added to $190 \mu \mathrm{L}$ of ABTS radical solution in a well of 96well plate. The mixture was shaken vigorously and allowed to stand in the dark at room temperature for $30 \mathrm{~min}$. Absorbance readings were taken at $734 \mathrm{~nm}$. The percent radical scavenging activity of extracts and standards against ABTS were calculated according to the following:

$$
\begin{aligned}
& \text { ABTS radical-scavenging activity }(\%)= \\
& \quad=\left[\left(\mathrm{A}_{0}-\mathrm{A}_{1}\right) / \mathrm{A}_{0}\right] \times 100
\end{aligned}
$$

where $A_{0}$ is the absorbance of the control (containing all reagents except the test extracts or compounds), and $A_{1}$ is the absorbance of the extracts/standards. Extracts or compounds concentration providing $50 \%$ inhibition $\left(\mathrm{IC}_{50}\right)$ was calculated from the graph plotting inhibition percentage against extracts concentration. Tests were carried out in triplicate. BHA, ascorbic acid and trolox were used as positive control.

\section{6. Quantitative Determination of the Total Phenolic Contents of Stachys Subnuda Extracts}

Total phenolic compound content of extracts was determined according to Gao et al. ${ }^{13}$ The assay was adapted to the 96 well microplate format. $10 \mu \mathrm{L}$ of extracts in various concentrations were mixed with $20 \mu \mathrm{L}$ Folin-Ciocalteu reagent (Sigma), $200 \mu \mathrm{L}$ of $\mathrm{H}_{2} \mathrm{O}$, and $100 \mu \mathrm{L}$ of $15 \% \mathrm{Na}_{2} \mathrm{CO}_{3}$ and the absorbance was measured at $765 \mathrm{~nm}$ after $2 \mathrm{~h}$ incu- 
bation at room temperature. Gallic acid was used as a standard and the total phenolic contents of extracts were expressed as $\mathrm{mg} / \mathrm{g}$ gallic acid equivalents (GAE)

\section{7. Quantitative Determination of the Total Flavonoid Contents of Stachys Subnuda Extracts}

Total flavonoid compound content of extracts was determined according to Zhang et al. ${ }^{14}$ The assay was adapted to the 96 well microplate format. $25 \mu \mathrm{L}$ of extracts in various concentrations were mixed with $125 \mu \mathrm{L}$ of $\mathrm{H}_{2} \mathrm{O}$, and $7.5 \mu \mathrm{L}$ of $5 \% \mathrm{NaNO}_{2}$. After $6 \mathrm{~min}, 15 \mu \mathrm{L}$ of $10 \% \mathrm{AlCl}_{3}$ solution was added and incubated for $5 \mathrm{~min}$, followed by the addition of $50 \mu \mathrm{L}$ of $1 \mathrm{M} \mathrm{NaOH}$ solution. Distilled water was added to bring the total volume to $250 \mu \mathrm{L}$, and the absorbance was immediately measured at $510 \mathrm{~nm}$ using a Shimadzu UV-1800 spectrometer. Catechin was used as a standard and total flavonoid content was expressed as $\mathrm{mg} / \mathrm{g}$ catechin equivalents (CE)

\section{8. Isolation of Active Compounds}

In antioxidant activity experiments, ethyl acetate extract showed the best antioxidant activity among all extracts. Therefore, ethyl acetate extract was chosen for isolation. The ethyl acetate extract $(2.02 \mathrm{~g})$ was fractionated by $\mathrm{CC}$ on silica gel, using a gradient system of $\mathrm{CHCl}_{3} / \mathrm{EtOAc/}$ $\mathrm{CH}_{3} \mathrm{OH}$ to yield twenty five fractions. Fractions showing similar TLC profiles were combined to give six sub-fractions (F7-F8: $1.00 \mathrm{~g}, \mathrm{F9}-\mathrm{F} 10: 0.46 \mathrm{~g}$, F11-F13: $0.20 \mathrm{~g}$, F14-F18: 0.15 g, F19-F22: 0.06 g, F23-F25: 0,04 g). DPPH activity test was performed on these fractions. It has been continued the isolation with F7-F8, having the highest DPPH radical scavenging activity and the most intense compound content on TLC among all fractions [DPPH radical inhibition rate at concentration of $10 \mu \mathrm{g} / \mathrm{mL}: 47 \%$ (F7-F8), 22\% (F9-F10), 16\% (F11-F13), 44\% (F14-F18), 32\% (F19-F22), 31\% (F23-F25)]. F7-F8 (1,0 g) was repeatedly chromatographed on a Sephadex LH-20 column, eluted with $\mathrm{CH}_{3} \mathrm{OH}$ and then combined sub-fractions was re-chromatographed by preparative TLC with $\mathrm{CHCl}_{3}$ : $\mathrm{CH}_{3} \mathrm{OH}: \mathrm{H}_{2} \mathrm{O}$ (4:1:2 drops) to give SS1 $(32 \mathrm{mg})$ and SS2 $(43.6 \mathrm{mg}$ ) (Figure 1, Detailed spectral data is included in supporting information).

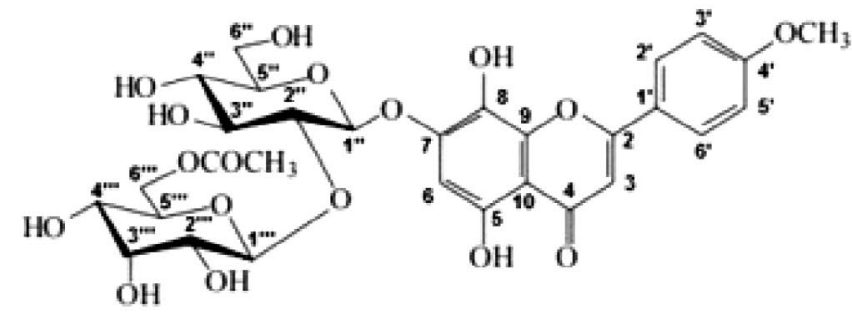

(SS1)

\section{9. LC-MS/MS Analysis}

LC-MS/MS analysis was carried out using an Absciex 3200 Q trap MS/MS dedector. Experiments were performed with a Shimadzu 20A HPLC system coupled to an Applied Biosystems 3200 Q-Trap LC- MS/MS instrument equipped with an ESI source operating in negative ion mode. For the chromatographic separation, ODS 150 $\times 4.6 \mathrm{~mm}$, i.d., $3 \mu \mathrm{m}$ particle size, octadecyl silica gel analytical column operating at $40^{\circ} \mathrm{C}$ has been used. The solvent flow rate was maintained at $0.5 \mathrm{~mL} / \mathrm{min}$. Detection was carried out with PDA detector. The elution gradient consisted of mobile phases (A) acetonitrile:water:formic acid $(10: 89: 1, \mathrm{v} / \mathrm{v} / \mathrm{v})$ and $(\mathrm{B})$ acetonitrile:water:formic acid $(89: 10: 1, \mathrm{v} / \mathrm{v} / \mathrm{v})$. The composition of $\mathrm{B}$ was increased from $10 \%$ to $100 \%$ in $40 \mathrm{~min}$. LC-ESI-MS/MS data were collected and processed by Analyst 1.6 software. For enhanced mass scan (EMS), the MS was operated at mass range of 100-1000 amu. Enhanced product ion spectra were measured from $\mathrm{m} / \mathrm{z} 100$ up to $m / z 1000$. Nitrogen was used as the collision gas, and the collision energy was set at 30 . The parameters were as follows: Collusion Energy Spread (CES)-0, Declustiring Potential (DP)-20, Enterance Potential (EP)-10, Curtain gas (CUR)-20, Gas Source 1 (GS1)50, Gas Source 2 (GS2)-50, CAD- medium, Ihe- on and Temperature (TEM)-600. For the IDA experiment, the criteria were arranged for ions greater than $100.000 \mathrm{~m} / z$ and smaller than $1000 \mathrm{~m} / z$, and excluded former target ions after 3.0 occurrence(s) for 3.000 seconds.

\section{10. Statistical Analysis}

The data were given as means \pm standard deviations and analysed by one-way analysis of variance (ANOVA) followed by the Tukey's multiple comparison tests using GraphPad Prism 5. Differences between means at $\mathrm{p}<0.05$ levels were considered significant.

\section{Results and Discussion}

In the present study, it was evaluated anti-inflammatory and antioxidant activities of major compounds isolated from ethyl acetate extract of aerial parts of endemic Stachys subnuda. Two acylated flavone glycosides, SS1 and

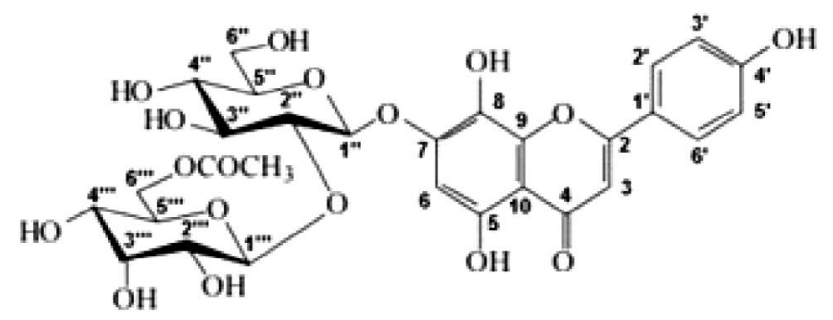

(SS2)

Figure 1. Chemical structures of major compounds isolated from S. subnuda 
SS2, were isolated as major compounds from active F7-F8 sub-fraction of ethyl acetate extract (SSEA) of S. subnuda aerial part (Figure 1). All isolated compounds were analyzed by spectroscopic methods $\left({ }^{1} \mathrm{H}\right.$ NMR and ${ }^{13} \mathrm{C}$ NMRAPT) and their data were compared with those reported in the literature. ${ }^{15,16}$ To the best of our knowledge, there is no study on flavonoids of S. subnuda. However, these compounds have been previously isolated from Stachys recta. ${ }^{17}$ In previous studies, it has been reported that different acetylated flavonoids have been isolated from other Stachys species. $5,6,9,17-19$

Seven phenolic compounds including quinic acid (SS3), 5-caffeoylquinic acid (SS4), isoscutellarein 7-O-allosyl(1-2)glucoside (SS5), isoscutellarein 7-O-[6"'-O-acetyl] allosyl $(1 \rightarrow 2)$ glucoside (SS2), 4'-O-methylisoscutellarein 7-O-allosyl $(1 \rightarrow 2)$ glucoside (SS6), 4'-O-methylisoscutellarein $\quad 7$-O-allosyl $(1 \rightarrow 2)$-[6"'-O-acetyl]-glucoside (SS1), 4'-O-methylisoscutellarein 7-O-[6"'-O-acetyl]-allosyl(1-2)[6"-O-acetyl]-glucoside (SS7)", were detected by LC/MS-MS (Figure 2) (Table 1).
The results of this analysis showed that the main phenolic compounds of the S. subnuda ethyl acetate extract are SS1 and SS2. Also, these two compounds were isolated from the ethyl acetate extract of $S$. subnuda in the present study. SS3 showed a pseudo molecular ion peak at $\mathrm{m} / z 191$ that fragmented to several ions at $m / z 173$ and $m / z 127$. This fragmentation pattern is characteristic for quinic acid. ${ }^{23}$ SS4 presented the molecular ion peak at $\mathrm{m} / z 353$ [M-H] $]^{-}$which fragmented to $\mathrm{m} / z 191$ (base peak) $\mathrm{m} / \mathrm{z} 179$, $\mathrm{m} / z 161$ and $\mathrm{m} / z 135$. According to Clifford and colleagues, this compound must be caffeoylquinic acids. Moreover, less amount of ion at $m / z 179$ indicates that the caffeic acid and quinic acid are linked at 3 positions. So, SS4 was identified as 3-caffeoylquinic acid. ${ }^{23}$ SS5 and SS2 presented pseudo molecular ion peaks at $\mathrm{m} / z 609$ and $\mathrm{m} / z$ 651, respectively. Both compounds showed the same aglycon ion at $m / z 285$. Luteolin, kaempferol, isoscutellarein etc. show the same molecular ion peak at $m / z 285[\mathrm{M}-\mathrm{H}]^{-}$. Several studies published previously about Stachys species, indicate that isoscutellarein is dominant flavonoid aglycon for Stachys

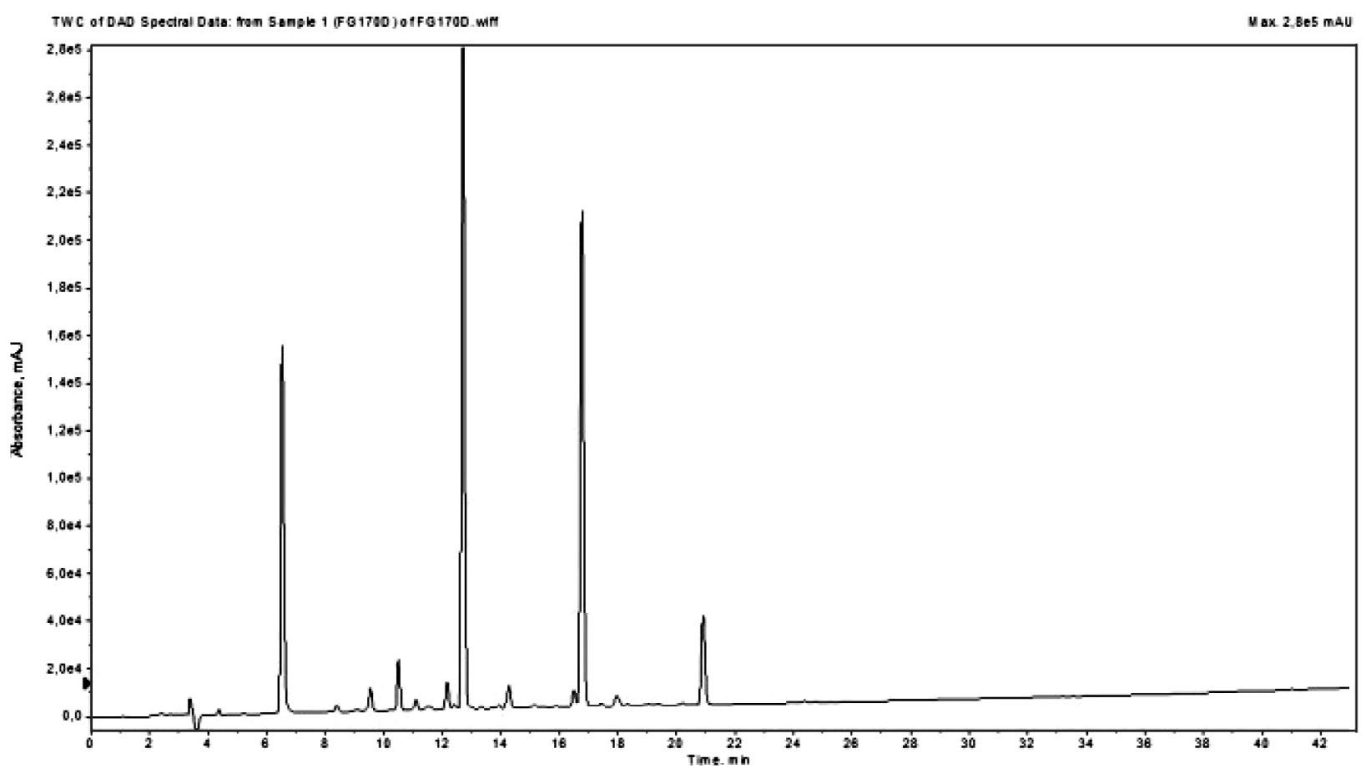

Figure 2. LC-MS/MS chromatogram of ethyl acetate extract of S. subnuda

Table 1. Characterization of phenolic compounds in the ethyl acetate extract of S. subnuda

\begin{tabular}{|c|c|c|c|c|c|}
\hline No & Rt min & {$[\mathrm{M}-\mathrm{H}]^{-} m / z$} & MS $^{2}$ & Identified as & References \\
\hline SS3 & 3.3 & 191 & 173,127 & Quinic acid & {$[20]$} \\
\hline SS4 & 6.7 & 353 & $191,179,161,135$ & 5-Caffeoylquinic acid & [21] \\
\hline SS5 & 10.7 & 609 & 429,285 & Isoscutellarein 7-O-allosyl(1-2)glucoside & {$[21]$} \\
\hline SS2 & 12.9 & 651 & $609,591,447,429,285$ & $\begin{array}{l}\text { Isoscutellarein } 7-O-\left[6^{\prime \prime \prime}-O \text {-acetyl }\right] \text { allosyl }(1 \rightarrow 2) \text { glucoside } \\
\text { (Main compound) }\end{array}$ & {$[20]$} \\
\hline SS6 & 14.5 & 623 & $461,299,284$ & 4'-O-methylisoscutellarein 7-O-allosyl $(1 \rightarrow 2)$ glucoside & {$[20]$} \\
\hline SS1 & 17.0 & 665 & 299,284 & $\begin{array}{l}4^{\prime} \text {-O-methylisoscutellarein } 7-O \text {-allosyl }(1 \rightarrow 2)-\left[6^{\prime \prime \prime}-O \text {-acetyl }\right] \\
\text {-glucoside }\end{array}$ & {$[20,22]$} \\
\hline SS7 & 21.2 & 707 & $\begin{array}{l}665,647,503,485 \\
443,351,299,284\end{array}$ & $\begin{array}{l}4^{\prime}-O-\text { Methylisoscutellarein } 7-O-\left[6^{\prime \prime \prime}-O \text {-acetyl }\right] \text {-allosyl } \\
(1-2)-\left[6^{\prime \prime}-O \text {-acetyl]-glucoside }\right.\end{array}$ & [20] \\
\hline
\end{tabular}


genus. $^{24,25}$ Therefore, isoscutellarein was determined as the aglycon of SS5 and SS2. (NMR spectra also supported that the isoscutellarein is an aglycon of this plant material). 324 amu difference between molecular ion peak and aglycon was indicated that isoscutellareain are linked with two-sugar unit. Moreover, the ion at $m / z 429\left([\mathrm{M}-\mathrm{H}]^{-}-180\right)$ indicates that glycosylation position of the sugars is $1 \rightarrow 2 . .^{22,25}$ So, according to literature data and MS spectrums, these compounds were identified as Isoscutellarein 7-O-allosyl (1-2) glucoside (SS5) and Isoscutellarein 7-O-[6"'-O-acetyl $]$ allosyl $(1 \rightarrow 2)$ glucoside (SS2). According to Petreska et al., there are two substances with the same molecular weight with SS2 which presents similar fragmentation characteristics. The difference between these two compounds is that the acetylation positions of the sugar are different from each other. ${ }^{22}$ NMR spectrum showed that sugar united acetylated at $6^{\prime \prime \prime}$ position for SS2 which was also isolated from the plant material. SS6, SS1 and SS7 showed a molecular ion peak at $m / z 623[\mathrm{M}-\mathrm{H}]^{-}, 665[\mathrm{M}-\mathrm{H}]^{-}$and 707 [M$\mathrm{H}]^{-}$, respectively. These compounds presented the same base peak. Ion at $\mathrm{m} / \mathrm{z} 299$ that fragmented at $\mathrm{m} / \mathrm{z} 284$ is due to the loss of a methyl unit. Methylisoscutellerain is a flavonoid, which is found in many Stachys species. ${ }^{24}$ Loss of 324 amu between SS6 and its aglycone indicates that SS6 is dihexoside of methylisoscutellerain. Loss of $366 \mathrm{amu}$ (dihexose+acetyl) from molecular ion peak indicates that SS1 is acetyldihexose of methyl isoscutellerain. The difference 408 amu between SS7 and its aglycon indicates that SS7 is diacetyldihexose of methyl isoscutellerain. According to this findings and literature data survey, SS6, SS1 and SS7 identified as $4^{\prime}$-O-methylisoscutellarein 7-O-allosyl $(1 \rightarrow 2)$ glucoside, $\quad 4^{\prime}$-O-methylisoscutellarein 7-O-allosyl $(1 \rightarrow 2)$-[6"' $-O$-acetyl]-glucoside and 4'-O-Methylisoscutellarein 7-O-[6"' -O-acetyl]-allosyl (1-2)-[6"'-O-acetyl]-glucoside, respectively.

All of the extracts except for the SSH extract were found to have a significant antioxidant activity. SSEA extract showed the highest antioxidant activity in DPPH and ABTS assays with $\mathrm{IC}_{50}$ values of 3.7 and $5.3 \mu \mathrm{g} / \mathrm{mL}$, respectively. Also, the highest total phenol and total flavonoid content were found in the SSEA $(219.4$ and $78.3 \mathrm{mg} / \mathrm{g}$, respectively) (Table 2). There are no reports on antioxidant activity of extracts and isolated flavonoids from Stachys subnuda but a large number of studies are available on different Stachys species in the literature. In these studies, Stachys species have been reported to exhibit a significant antioxidant activity. In one of these studies, Erdemoglu et al. ${ }^{26}$ reported that water extract of Stachys byzantine was active against the DPPH radical with an $\mathrm{IC}_{50}$ value of 640 $\mu \mathrm{g} / \mathrm{mL}$. In another study, the radical scavenging activity of Stachys glutinosa ethanol extract was found to be $280 \mu \mathrm{g} /$ $\mathrm{mL}$ and $320 \mu \mathrm{g} / \mathrm{mL}$ of $\mathrm{IC}_{50}$ values in DPPH and ABTS experiments, respectively. ${ }^{8}$ Ghasemi et al. $^{27}$ reported that methanol extract of Stachys lavandulifolia against DPPH and ABTS radicals had antioxidant activity with the $\mathrm{IC}_{50}$ values of 2320 and $3770 \mu \mathrm{g} / \mathrm{mL}$, respectively. In the same study, it had been suggested that total phenolic and flavonoid contents of this species were $99 \mathrm{mg} / \mathrm{g}$ and $9.05 \mathrm{mg} / \mathrm{g}$, respectively. Also, Šliumpaitè et al. ${ }^{28}$ reported that total phenol content of methanol extracts of Stachys officinalis was $61.2 \mathrm{mg} / \mathrm{g}$, expressed as gallic acid equivalent. When compared these results with our current study, it can be seen that Stachys subnuda has a better antioxidant activity and a higher total phenolic and flavonoid content. Phenolic compounds present in plants are known to be powerful antioxidants. ${ }^{29}$ Therefore, these compounds may be responsible for the antioxidant activity of the plant.

Isolated two acylated flavone glycosides were tested for their DPPH and ABTS radical scavenging activity. SS1 showed the highest antioxidant activity in DPPH and ABTS assays with $\mathrm{IC}_{50}$ values of 2.35 and $1.98 \mu \mathrm{g} / \mathrm{mL}$, followed by SS2 (13.94 and $12.76 \mu \mathrm{g} / \mathrm{mL})$, respectively. Also, SS1 showed better antioxidant activity compared to standards (Table 3). Delazar et al. ${ }^{18}$ investigated antioxidant activity of two flavonoid glycosides, chrysoeriol 7-O-[6-O-acetyl- $\beta$-D-allopyranosyl]-(1'2)- $\beta$-D-glucopyranoside and apigenin $7-O-\beta$-D-(6- $p$-coumaroyl)-glucopyranoside, isolated from Stachys bombycina and these compounds have been demonstrated to possess strong antioxidant activity with of $\mathrm{IC}_{50}$ values of 12.5 and $0.77 \mu \mathrm{g} /$

Table 2. Antioxidant activities, total phenolic and flavonoid contents of various extracts from aerial parts $S$. subnuda

\begin{tabular}{|c|c|c|c|c|c|}
\hline \multirow[t]{2}{*}{ Extracts $^{*}$} & \multirow{2}{*}{$\begin{array}{l}\text { DPPH activity } \\
\text { IC }_{50}\left(\mu \mathrm{gmL}^{-1}\right)^{\star *}\end{array}$} & \multicolumn{2}{|c|}{ ABTS activity } & \multirow{2}{*}{$\begin{array}{c}\text { TPC }^{\star * * *} \\
(\mathrm{mg} \mathrm{GAE} / \mathrm{g} \text { extract })^{\mathrm{c}}\end{array}$} & \multirow{2}{*}{$\begin{array}{c}\text { TFC }^{\star * * * *} \\
\left(\mathrm{mg} \mathrm{CE} / \text { g extract }^{d}\right.\end{array}$} \\
\hline & & $\mathrm{IC}_{50}\left(\mu \mathrm{gmL}^{-1}\right)$ & mM TE/g extract ${ }^{* * *}$ & & \\
\hline SSH & $180.1 \pm 0.26^{\mathrm{e}}$ & $97.0 \pm 1.37^{c}$ & $5.1 \pm 0.79^{\mathrm{a}}$ & $33.6 \pm 1.54^{\mathrm{a}}$ & $10.0 \pm 0.82^{\mathrm{a}}$ \\
\hline SSC & $13.4 \pm 0.00^{\mathrm{b}}$ & $8.2 \pm 0.35^{\mathrm{a}}$ & $62.4 \pm 0.92^{\mathrm{d}}$ & $112.3 \pm 3.29^{c}$ & $41.5 \pm 1.92^{\mathrm{b}}$ \\
\hline SSEA & $3.7 \pm 1.00^{\mathrm{a}}$ & $5.3 \pm 0.20^{\mathrm{a}}$ & $99.2 \pm 2.02^{\mathrm{e}}$ & $219.4 \pm 2.18^{d}$ & $78.3 \pm 3.13^{\mathrm{d}}$ \\
\hline SSM & $24.4 \pm 0.45^{\mathrm{b}}$ & $16.0 \pm 0.46^{\mathrm{b}}$ & $31.2 \pm 0.19^{c}$ & $112.6 \pm 1.69^{c}$ & $57.4 \pm 1.63^{\mathrm{c}}$ \\
\hline SSAM & $39.5 \pm 1.03^{\mathrm{d}}$ & $21.8 \pm 1.21^{\mathrm{b}}$ & $20.9 \pm 1.65^{\mathrm{b}}$ & $90.36 \pm 2.83^{b}$ & $63.5 \pm 1.42^{c}$ \\
\hline
\end{tabular}

${ }^{*}$ The methanol, $n$-hexane, chloroform, ethyl acetate and aqueous methanol extracts were coded as SSM, SSH, SSC, SSEA and SSAM, respectively.

${ }^{* *}$ Values corresponding to the amount of extract required to scavenge $50 \%$ of radicals present in the reaction mixture.

${ }_{* *}^{*}$ ABTS radical scavenging activity were expressed as trolox equivalent (TE)

${ }_{* * * *}$ Total phenolic content (TPC) was expressed as gallic acid equivalent (GAE).

$* * * * *$ Total flavonoid content (TFC) was expressed as catechin equivalent (CE). Each value in the table is represented as mean $\pm \operatorname{SD}(n=3)$. Different letter superscripts in the same column indicate significant differences $(p<0.05)$. 
Table 3. Antioxidant and anti-inflammatory activities of compounds isolated from Stachys subnuda and standards

\begin{tabular}{lccc}
\hline $\begin{array}{l}\text { Compounds/ } \\
\text { Standards }\end{array}$ & DPPH activity & ABTS activity & $\begin{array}{c}\text { Anti-inflammatory } \\
\text { activity }\end{array}$ \\
\hline & & IC $_{\mathbf{5 0}}\left(\boldsymbol{\mu g m L} \mathbf{H}^{-\mathbf{1}}\right)$ & \\
SS1 & $2.35 \pm 0,00^{\mathrm{a}}$ & $1.98 \pm 0,01^{\mathrm{a}}$ & $47.23 \pm 1.95^{\mathrm{b}}$ \\
SS2 & $13.94 \pm 1,65^{\mathrm{b}}$ & $12.76 \pm 0,00^{\mathrm{b}}$ & $41.60 \pm 2.09^{\mathrm{b}}$ \\
Ascorbic acid & $17.60 \pm 0.37^{\mathrm{b}}$ & $14.50 \pm 0.32^{\mathrm{b}}$ & \\
Trolox & $14.54 \pm 0.18^{\mathrm{b}}$ & $13.00 \pm 0.21^{\mathrm{b}}$ & \\
Butylated hydroxyanisole & $57.15 \pm 0.09^{\mathrm{c}}$ & $17.06 \pm 0.58^{\mathrm{b}}$ & \\
Indomethacin & & & $22.39 \pm 0.26^{\mathrm{a}}$ \\
\hline
\end{tabular}

Each value in the table is represented as mean $\pm S D(n=3)$. Different letter superscripts in the same column indicate significant differences $(p<0.05)$.

$\mathrm{mL}$, respectively. Similarly, two active acylated flavone glycosides isolated in present study, especially SS1, showed strong antioxidant activity. It has also been found that the SS1 has very good antioxidant activity when compared to the standards. When the results of the antioxidant activity of the ethyl acetate extract are compared with the isolated compounds, it might be considered that these compounds are responsible for the activity of the ethyl acetate extract. Also, flavonoids are generally known to be compounds with antioxidant activity. ${ }^{30}$ For this reason, it can be assumed that these groups of compounds are responsible for the activity of the extract.

Each value in the table is represented as mean $\pm S D$ $(\mathrm{n}=3)$. Different letter superscripts in the same column indicate significant differences $(p<0.05)$.

SS1 and SS2 displayed 5-lipoxygenase (5-LOX) inhibitory activity with $\mathrm{IC}_{50}$ values of 47.23 and $41.60 \mu \mathrm{g} / \mathrm{mL}$ (Table 3). As far as we know, there is no report on anti-inflammatory activity of these compounds. However, in a previous study, Alcaraz et al. ${ }^{31}$ reported that isoscutellarein, a flavonoid aglycone, inhibited 15-lipoxygenase (15-LOX) activity. Also, Yoshimoto et al. ${ }^{32}$ have shown that flavonoids are potent inhibitors of 5-lipoxygenase. Similarly, SS1 and SS2, the flavonoids isolated from ethyl acetate extract of $S$. subnuda aerial part in our current study, showed good anti-lipoxygenase activity and these results are compatible with previous findings.

\section{Conclusion}

These results indicate that SS1 and SS2 with other compounds present in ethyl acetate extract of Stachys subnuda may be responsible for the anti-inflammatory and antioxidant activity of the extract. Also, these results show that SS1 and SS2 isolated from Stachys subnuda have strong antioxidant and good anti-inflammatory activity. These isolated compounds can be used as a natural antioxidant source in food, pharmaceutical and cosmetic industries. However, further studies, such as in vivo tests, are needed to clarify the antioxidant and anti-inflammatory effects of these compounds.

\section{Conflicts of interest}

The authors declare no conflict of interest.

\section{Acknowledgements}

This work was supported by a grant from the Scientific and Technological Research Council of Turkey (TUBITAK), under the project 1919B011603877 (Code: 2209-A).

\section{Appendix A. Supplementary Data}

Spectral data of compounds isolated from ethyl acetate extract of aerial parts of Endemic Stachys subnuda can be found in Appendix.

\section{List of Abbreviations}

\section{5-LOX: 5-lipoxygenase}

ABTS: 2,2'-azino-bis-3-ethylbenzthiazoline-6-sulphonic acid

BHA: Butylated hydroxyanisole

CE: Catechin equivalent

DMSO: Dimethyl Sulfoxide

DPPH: 1,1-diphenyl-2-picrylhydrazyl

EtOAc: Ethyl acetate

F7-F8: Fraction 7- Fraction 8

F9-F10: Fraction 9- Fraction 10

F11-F13: Fraction 11- Fraction 13

F14-F18: Fraction 14- Fraction 18

F19-F22: Fraction 19- Fraction 22

F23-F25: Fraction 23- Fraction 25

GAE: Gallic acid equivalent

HPLC: High Performance Liquid Chromatography

$\mathrm{IC}_{50}$ : The concentration of extract that sweeps $50 \%$ of the radical or inhibits the activity of the enzyme by $50 \%$

LC-MS/MS: Liquid chromatography linked to tandem mass spectrometry

MARE: Herbarium of the Faculty of Pharmacy, Marmara University

ODS: Octadecyl-silica

SS1: 4'-O-methylisoscutellarein-7-O-2"-O-(6"'-O-acetyl$\beta$-D-allopyranosyl)- $\beta$-D glucopyranoside 
SS2: İsoscutellarein-7-O-2"'-O-(6"'-O-acetyl- $\beta$-Dallopyranosyl)- $\beta$-D-glucopyranoside

SS3: Quinic acid

SS4: 5-Caffeoylquinic acid

SS5: Isoscutellarein 7-O-allosyl(1 -2)glucoside

SS6: 4'-O-methylisoscutellarein 7-O-allosyl $(1 \rightarrow 2)$ glucoside

SS7: 4'-O-Methylisoscutellarein 7-O-[6"'-O-acetyl]allosyl(1-2)-[6"-O-acetyl]-glucoside

SSM: Methanol extract of Stachys subnuda

SSH: Hexane fraction of methanol extract of Stachys subnuda

SSC: Chloroform fraction of methanol extract of Stachys subnuda

SSEA: Ethyl acetate fraction of methanol extract of Stachys subnuda

SSAM: Aqueous methanol fraction of methanol extract of Stachys subnuda

TE: Trolox equivalent

TFC: Total flavonoid content

TLC: Thin layer chromatography

TPC: Total phenolic content

\section{References}

1. V. B. Vundac, H. W. Pfeifhofer, A. H. Brantner, Z. Males, M. Plazibat, Biochem Syst Ecol 2006, 34, 875-881.

DOI:10.1016/j.bse.2006.04.010

2. G. İscan, Y. B. Kose, B. Demirci, Anadolu Univ J Sci Technol-C Life Sci Biotechnol 2015, 4, 41-47.

3. A. C. Gören, Rec Nat Prod 2014, 8, 71-82.

4. A. Sen, M. Kurkcuoglu, L. Bitis, A. Dogan, K. H. C. Baser, J Essent Oil Res, 2019, 31, 326-334.

DOI:10.1080/10412905.2019.1567399

5. A. Venditti, A. Bianco, M. Nicoletti, L. Quassinti, M. Bramucci, G. Lupidi, LA. Vitali, F. Papa, S. Vittori, D. Petrelli, L. Maleci Bini, C. Giuliani, F. Maggi, Chem Biodivers 2014, 11, 245-261. DOI:10.1002/cbdv.201300253

6. A. Venditti, A. Bianco, L. Quassinti, M. Bramucci, G. Lupidi, S. Damiano, F. Papa, S. Vittori, L. Maleci Bini, C. Giuliani, D. Lucarini, F. Maggi, Chem Biodivers 2015, 12, 1172-1183. DOI:10.1002/cbdv.201400275

7. Ael-H Mohamed, NS. Mohamed, Nat Prod Res 2014, 28, 3034. DOI:10.1080/14786419.2013.830217

8. L. Leporini, L. Menghini, M. Foddai, G. L. Petretto, M. Chessa, B. Tirillini, G. Pintore, Nat Prod Res 2015, 29, 899-907. DOI:10.1080/14786419.2014.955490

9. S. Laggoune, A. Zeghib, A. Kabouche, Z. Kabouche, Y. A. Maklad, F. Leon, I. Brouard, J. Bermejo, C. A. Calliste, J. L. Duroux, Arabian J Chem 2016, 9, S191-S197.

DOI:10.1016/j.arabjc.2011.03.005

10. A. H. Ebrahimabadi, E. H. Ebrahimabadi, Z. Djafari-Bidgoli, F. J. Kashi, A. Mazoochi, H. Batooli, Food Chem 2010, 119, 452-458. DOI:10.1016/j.foodchem.2009.06.037
11. N. Phosrithong, N. Nuchtavorn, Eur J Integr Med 2016, 8, 281-285. DOI:10.1016/j.eujim.2015.10.002

12. Y. Zou, S.K. Chang, Y. Gu, S. Y. Qian, J Agric Food Chem, 2011, 59, 2268-2276. DOI:10.1021/jf104640k

13. X. Gao, M. Ohlander, N. Jeppsson, L. Björk, V. Trajkovski, J Agric Food Chem 2000, 48, 1485-1490.

DOI:10.1021/jf991072g

14. R. Zhang, Q. Zeng, Y. Deng, M. Zhang, Z. Wei, Y. Zhan, X. Tang, Food Chem 2013, 136, 1169-1176.

DOI:10.1016/j.foodchem.2012.09.085

15. D. C. Albach, R. J. Grayer, S. R. Jensen, F. Ozgokce, N. C. Veitch, Phytochemistry, 2003, 64, 1295-1301.

DOI:10.1016/j.phytochem.2003.08.012

16. I. Saracoglu, Ş. Harput, Y. Ogihara, Turk J Chem 2004, 28, 751-759.

17. A. Lenherr, M. F. Lahloub, O. Sticher, Phytochemistry, 1984, 23, 2343-2345. DOI:10.1016/S0031-9422(00)80548-8

18. A. Delazar, S. Celik, R. S. Göktürk, O. Unal, L. Nahar, S. D. Sarker, Pharmazie 2005, 60, 878-880.

19. B. Tepe, S. Degerli, S. Arslan, E. Malatyali, C. Sarikurkcu, Fitoterapia 2011, 82, 237-246. DOI:10.1016/j.fitote.2010.10.006

20. J. Petreska Stanoeva, D. Bagashovska, M. Stefova, Maced J Chem Chem En 2012, 31, 229-243.

21. J. Petreska, M. Stefova, F. Ferreres, D. A. Moreno, F. A. Tomás-Barberán, G. Stefkov, S. Kulevanova, A. Gil-Izquierdo, Food Chem 2011, 125, 13-20.

DOI:10.1016/j.foodchem.2010.08.019

22. J. Petreska, G. Stefkov, S. Kulevanova, K. Alipieva, V. Bankova, M. Stefova, Nat Prod Commun 2011, 6, 21-30.

DOI:10.1177/1934578X1100600107

23. M. N. Clifford, K. L. Johnston, S. Knight, N. Kuhnert, J Agric Food Chem 2003, 51, 2900-2911. DOI:10.1021/jf026187q

24. A. Ulubelen, G. Topcu, U. Kolak, in: R. Atta ur (Ed.): Labiatae flavonoids and their bioactivity, Studies in Natural Products Chemistry, Elsevier. 2005, pp. 233-302.

DOI:10.1016/S1572-5995(05)80035-3

25. O. R. Pereira, M. R. Domingues, A. M. Silva, S. M. Cardoso, Food Res Inter 2012, 48, 330-335.

DOI:10.1016/j.foodres.2012.04.009

26. N. Erdemoglu, N. N. Turan, I. Cakici, B. Sener, A. Aydin, Phytother Res 2006, 20, 9-13. DOI:10.1002/ptr.1816

27. A. Ghasemi Pirbalouti, A. Siahpoosh, M. Setayesh, L. Craker, Med Food 2014, 17, 1151-1157. DOI:10.1089/jmf.2013.0057

28. I. Šliumpaite, P.R. Venskutonis, M. Murkovic, O. Ragažinskienè, Ind Crops Prod 2013, 50, 715-722.

DOI:10.1016/j.indcrop.2013.08.024

29. P. Kapewangolo, J. J. Omolo, R. Bruwer, P. Fonteh, and D. Meyer, I Inflam 2015, 12, 1-13. DOI:10.1186/s12950-015-0049-4

30. K. E. Heim, A. R. Tagliaferro, D.J. Bobilya, J Nutr Biochem 2002, 13, 572-584. DOI:10.1016/S0955-2863(02)00208-5

31. M. J. Alcaraz, J. R. Hoult, Arch Int Pharmacodyn Ther, 1985, $278,4-12$.

32. T. Yoshimoto, M. Furukawa, S. Yamamoto, T. Horie, S. Watanabe-Kohno, Biochem Biophys Res Commun 1983, 116, 612-618. DOI:10.1016/0006-291X(83)90568-5 


\section{Povzetek}

V tej študiji, smo poročali o protivnetni in antioksidativni dejavnosti dveh aciliranih izoscutelarinskih glukozidov, izoliranih iz etil acetatnega ekstrakta Stachys subnuda it dela zraka. $4^{\prime}$-o-metilisoscutelaren-7-O-2 ', -O- $\left(6^{\prime \prime \prime}-\mathrm{O}\right.$-acetil- $\beta$-D-alopiranosil)- $\beta$-D-glucopiranosid (1) in izooscutelaren-7-O-2"-O-(6 "'-O-acetil- $\beta$-D-alopiranosl)- $\beta$-D-gluopiranoside (2) so bile izolirane kot glavne spojine iz etil acetatnega izvleček (EAE). Tudi 2 derivata hidroksicinične kisline, in 5 isoscutelaren glukozidni derivati v EAE so bili najdeni $\mathrm{z}$ uporabo LC-MS/MS. Spojina $1 \mathrm{z}$ IC50 vrednostjo 2,35 ve 1,98 $\mu \mathrm{g} / \mathrm{mL}$ in spojina 2 , z IC50 vrednosti $13,94 \mathrm{ve} 12,76 \mu \mathrm{g} / \mathrm{mL}$, je pokazala dokaj močno antioksidantno aktivnost proti radikalom DPPH in ABTS. Spojini 1 in 2 sta inhibirali 5-lipooksigenazno (5-LOX) aktivnost z IC50 vrednostmi približno 47,23 in 41,60 $\mu \mathrm{g} / \mathrm{mL}$. Rezultati so pokazali, da imajo izolirane spojine pomembno protivnetno in antioksidativno zmožnost. Acetilirane flavonoidni glikozidi so bili prvič poročani za Stachys subnuda. Tudi njihove dejavnosti so bile prvič preiskane v tej študiji. 